\title{
多角的貿易協定と保健衛生政策
}

宮城島一明* 佐藤 大作 ${ }^{* *}$ 中原 俊隆 ${ }^{*}$

\section{Multilateral Trade Agreements and National Health Policies}

\section{Kazuaki MIYAGISHIMA* , Daisaku SATO** and Toshitaka NAKAHARA*}

The Uruguary Round of Multilateral Trade Negotiations resulted in the establishment of the World Trade Organization (WTO) in January 1995. Several multilateral trade agreements, which are integral part of the WTO Agreements, have considerable health repercussions, particularly in food safety, pharmaceutical market and trade in health services. The WTO agreements thus have potential to profoundly influence health policies of the member governments and the level of public health and welfare acchieved thereby.

The analysis of the new trade environment has revealed differential public health impacts on developing and industrialized countries. Whilst the actual effects of the WTO agreements on developing countries have not yet been fully understood, these countries will soon have to comply with the entire range of the duties under the agreements as the agreed initial delay period expires.

The creation of transnational markets for foods and drugs and the deregulation process of health services may be one of the policy options for governments in search of increased efficiency and productivity in health and social services. In the 21 st century where further liberalization of trade and investment is expected to take effect, each government will be obliged to maintain its economic advantages by offering a more competitive and efficacious social security system.

Key words: health and trade, international standard, international harmonization, intellectual property rights, health service, World Trade Organization (WTO)

保健と貿易，国際基準，国際調和，知的所有権，保健医療サービス，世界貿易機関（WTO）

\section{１緒言}

保健医療と社会福祉の制度，あるいはこれに， 健康な市民生活の前提となる環境対策までを含め
たものは, 広い意味での社会制度の重要な一部分 である.その現時点での水準は各国民が歴史の中 で獲得してきたものであり, 各国固有の社会的財 であると考えられる，従って，各国民が自国の保

\footnotetext{
*京都大学大学院医学研究科社会医学系専攻社会予防医学講座公衆衛生学

**前 - 世界保健機関医薬品管理政策部

${ }^{*}$ Department of Public Health, Graduate School of Medicine, Kyoto University

** Formerly, Division of Drug Management and Policies, World Health Organization
} 
健福祉制度を含めた社会経済文化の総体に強い愛 着を持つことは驚くに值しない。むしろ，冷戦の 終焉を受けて加速する経済のグローバル化の中 で，思想・政治体制という伝統的な属性に代わっ て，その国特有の文化や社会的制度が一国のアイ デンティティを構成する重要な要素としてクロー ズアップされつつある。

言い換えるならば，今日，「ある国の国民の一 員である」ということの意味は，価值観・世界観 を共有しているということに留まらず，その国の 特色ある社会福祉機構の一員として，応分の社会 保障負担を負うと同時に受益者として給付を受け る権利を持つということでもある．近代・現代史 において西欧型社会の国家観が国民国家的概念か ら福祉国家的概念へと変容する過程で，国家の持 つ後者の意義が日常的市民生活において前者を上 回るようになったともいえるであろう.

個人の内面における国家観が大きな変革を遂げ つつあるなか, グローバル・ヴィレッジという言 葉に象徵されるように，個人や企業が自由に国境 を越えて活動する経済圈の構築が地球的規模で進 行している. その過程に㧍いて，一方では自由な 経済活動を欲する企業の側から，もう一方では経 済立地条件における競争力を他国と同等に保とう とする各国政府の側から, 経済活動・労働市場の インフラストラクチャーとしての各国の社会制度 を, 国家間で相互に調和していく要請が強まって いる. その反作用として, 各国の人々が, 近代福 祉国家の歴史的財産としての社会制度が国際社会 の変革圧力を受けることに対して敏感に反応する ようになっている（Wallach, 1998).

従って, 保健衛生と経済・貿易の連関について 考える際には, 各国の独自性あるいは社会的既得 権を守ろうとする保守的なモーメントと, 各国の 社会的基盤の共通化・調和化を実現しようという モーメントの両者を考慮する必要がある。また， 保健と貿易の相互関係に関する様相は, 先進工業 国と発展途上国において必ずしも同じではなく， 南北問題の要素も考慮する必要がある.

貿易自由化を旗印に世界貿易機関（World
Trade Organization，WTO）が発足して既に4 年が経過した。WTOの登場によって, 経済と貿 易を中心としつつ他の関連領域をも巻き込む新た なゲームが国家間で始まったわけである。しかし ながら，我が国においては，その直接的影響のご く一部，すなわち，農産品の貿易自由化と金融・ 保険業界の規制緩和の側面のみが論じられる傾向 にある. 本論の目的は, WTOの登場以来, 変貌 を遂げつつある保健衛生関連分野の諸条件を明ら かにし，WTOに代表される多国間貿易協定の枠 組みが保健医療領域にもたらす影響について考察 を加えることにある.

\section{II ウルグァイ・ラウンドの成果と WTOの枠組み}

ウルグアイ・ラウンド交渉とは, 関税および貿 易に関する一般協定 (General Agreement on Tariffs and Trade, GATT) の枠組みの中で行 われた第 8 次多角的関税・貿易交涉であり，1986 年 9 月にウルグアイのプンタ・デル・エステでの 閣僚会議に始まり，1994年4月にモロッコのマラ ケシュで開催された貿易交渉委員会の最終会合を 以って終結した。ウルグアイ・ラウンドにおいて は，極めて広い貿易分野が交渉の対象となり， 数々の斬新な多角的貿易協定が合意された。その 結果, 従来のGATT 事務局に代わって, 世界貿 易機関（World Trade Organization, WTO）が 1995年 1 月に発足した。

自由貿易を振興するための多角的枠組みの基礎 は，1947年に合意された関税および貿易に関す る一般協定（GATT1947）に遡る. 無差別待遇, 互恵主義, 関税による保護, 透明性の原則などの 重要な基本的ルールを含むこの合意は，1994年 の関税掞よび貿易に関する一般協定（GAT T 1994）の構成部分の一つとなり, 今日に至ってい る.

保健医療に関係する貿易上のルールが，WTO 発足以前に全く存在していなかったわけではな い. 最も重要なものとしては，「GATT加盟国相 互の不当な差別あるいは貿易上の障壁として用い 
られない限り，ヒトの生命と健康を保護するのに 必要な措置を各国が講ずることを妨げない」とい うGATT1947の第20条の規定があった。つまり， WTO 発足以前から, 保健衛生上の必要があれば, 貿易制限的な規制を設けることが各国の主権の一 部として認められていたわけである.

1973 年から 1979 年にかけての第 7 次多角的貿 易交渉（東京ラウンド）に扔いては，農産品や工 業製品を含めた商品全体に関して，不当な国内規 格・基準の押し付けが非関税障壁として用いられ ることがないようにするため，貿易の技術的障害 に関する協定 (Agreement on Technical Barriers to Trade, TBT協定）が合意された. しかし ながら，TBT協定は参加を希望する一部の国の 間だけで有効な協定であるに留まり，GATT加 盟国全体には適用されなかった。

円滑な貿易と適切な保健の確保を両立させてい く上で，GATT20条とTBT協定だけに依存する には，いくつかの困難があった.

第一に，何が「ヒトの生命と健康を保護するの に必要」な措置に該当するのかを判定する具体的 基準がなかったことである．つまり，輸入国の立 場からは必要と考えられる衛生的措置が, 輸出国 の視点からは明確な貿易障壁であると受け取られ る事例が生じたとき，その状況を客観的に分析す るための手段が不十分であった。ウルグアイ・ラ ウンド交渉が広範な農産品の関税聥減を目指して いただけに，多くの国が非関税措置に名を借りた 国産品の保護，すなわち貿易障壁の構築に傾斜し ていくのではないかという懸念が早期から指摘さ れており,ここに何らかの対策が必要とされてい た。

第二に，技術的障壁をめぐる貿易紛争を未然に 防止するには，各国が相互に規格・基準を世界規 模で調和していくことが不可欠であるが，その国 際調和を強力に推進するための仕組みが欠けてい た.

第三に, GATT1947は商品としての「モノ」 だけを対象としており，医薬品の開発に伴う特許 保護, 国境を越える保健サービスなどの問題は,
GATTの対集外であった。

第四に，個別の貿易紛争を効率的に処理するた めの紛争裁定機能が存在しなかった。つまり, 旧 GATTの紛争調停パネルの裁決は, 当事者の一 方が拒否すれば発効しなかったという問題であ る.

このような問題認識のもとでウルグアイ・ラウ ンド交渉は行われ，その結果，大きな变革がもた らされた，そのうち，保健衛生分野に関わるもの を列挙すると次のようになる。第一に, TBT協 定が複数国間協定から多角的協定に格上げされ た。第二に，従前の TBT 協定の中から食品や動 植物を取り出す形で, 衛生・検疫措置に関する新 しい協定（後述のSPS協定）が結ばれ，非関税 措置の正当性を評価するための具体的ルールが定 められた．第三に，「モノ」の対極に位置する存 在としての「サービス」を対象とする多角的協定 が新たに結ばれた、第四に，知的所有権に関する 初めての貿易協定が結ばれた．第五に，貿易紛争 の調停機能が強化され実効性が高まった（WTO， 1995 ；Davey，1997)。これらに加えて，WTO に加盟しょうとする国はすべての多角的協定を加 盟と同時に受け入れるという方式が採用された。

このように，WTOの発足とともに，ヒトの健 康を守るための輸出入制限措置の必要性を肯定し つつも貿易全般を促進し国際基準の調和を推進す るための強力な国際的機構が誕生した.

WTOの協定のなかには，サービスに関する協 定など，当初，発展途上国が採択に乗り気でない ものもあった．しかしながら，協定締結に当たっ て法制度的・技術的基盤整備を行わなければなら ない発展途上国には技術援助が提供されるべきで あるとの条項が多くの協定の盛り込まれたことな どにより, 多数の発展途上国のWTOへの参加が 実現した（Croome，1995）。さらに，いくつかの 分野については, WTO 発足時から起算して 3 年 から 5 年の期限付きで, 発展途上国に対し特定の 義務覆行が免除された。

こうして誕生したWTOの多角的貿易協定の中 で，ヒトの健康に直接関係する主なものは 4 つあ 
表 1 保健衛生に関係する WTO 協定

\begin{tabular}{ll}
\hline WTO 協定の略称 & \multicolumn{1}{c}{ 対象となる保健衛生分野 } \\
\hline SPS 協定 & $\begin{array}{l}\text { 食品・動物・植物に関する衛生・検疫 } \\
\text { 措置 }\end{array}$ \\
\hline TBT 協定 & 医薬品, 医療機器 \\
\hline TRIPS 協定 & 医薬品・医療機器に関する知的所有権 \\
\hline GATS & 保健医療サービス \\
\hline
\end{tabular}

る(表 1). 食品衛生分野, 医薬品・医療機器分 野, 保健医療サービス分野の順に, WTO協定に よって何が変わったかあるいは変わりつつあるか を検証したい.

\section{III 食品衛生分野}

\section{1. 食品規格の国際調和}

衛生植物検疫措置の適用に関する協定 (Agreement on the Application of Sanitary and Phytosanitary Measures, SPS協定）は，東京ラ ウンドのTBT協定をモデルとして生まれた新し い協定であり，食品・動植物を対象とする (GATT，1994）。この協定の画期的たる所以は, 科学的な影響評価つまり危険評価（Risk Assessment）を合理的衛生措置の基本と定めたことで ある．言い換えるなら，WTO加盟国は，自国の 衛生措置, 例えば, 輸入検査基準, 検疫措置など の根拠について他国から疑問を呈されたとき，そ の科学的根拠を示すことを迫られることになった (SPS協定第 5 条)。さらにSPS協定は, 食品衛 生・動物検疫・植物検疫の各分野において既存の 国際的標準化組織が制定する国際基準に主要な指 標としての地位を与え，これに向けて各国の制度 の調和を図っていくことにより，科学的合理性の ない貿易障壁の発生を未然に防ぐと同時に，世界 中の消費者の健康を適切かつ統一的な衛生基準に よって保護することを意図している。

現在までに認定された国際基準は，(1)国連食 糧農業機関（FAO）と世界保健機関（WHO）の 共同食品規格委員会 (Codex Alimentarius Commission，CAC）の定める国際食品規格のうち食
品衛生に関する部分，（2）国際獣疫事務局（Office international des épizooties，OIE）の定める 動物疾病・人畜共通感染症に関する規則, (3) FAOに事務局の置かれている国際植物防疫条約 (International Plant Protection Convention, IPPC）の枠組みの中で定められる植物検疫に関 する規定，この三者である．ヒトの健康，すなわ ち食品に関して最も重要なのはCACの定める食 品規格であり, 残留農薬・獣医薬品や食品添加物 に関する基準，衛生的食品製造過程に関する基準 などが含まれる．なお，WTO加盟国の間で合意 が得られれば, 適宜, 上記以外の国際基準を追加 指定することができるとされているが，まだ新た な国際基準の認定は行われていない.

しかし，SPS協定の下でCACの食品規格が強 制力を持つようになったとみなすのは，必ずしも 正確ではない。第一に，CACの食品規格には食 品の安全性に関する事項だけでなく, 食品の定義 や品質基準など，円滑な商取引を促進するための 事項も含まれており，これらはTBT協定との関 連でこそ意義を持つものの, SPS協定の下で直ち に効力があるわけではない，第二に，CACの規 格は，あくまでも，それを遵守している限り，当 該衛生措置の科学的合理性を個別に正当化する義 務が免除されるに過ぎず，科学的かつ合理的な危 険評価に基づいてさえいれば，より厳しい基準を 採用することを妨げない．第三に，CACの規格 よりも緩い基準を各国が基準に採用することは， 消費者の健康保護の観点から倫理的問題はあると しても，WTOのルールには違反しない.ただし， 外国からの輸入食品に対してCAC規格並みの基 準を課す一方，国産の同種食品に対してより緩い 基準を適用することは，GATTの内外無差別原 則に反する（WHO， 1998）。

SPS協定に基づくWTO設立後の貿易紛争とし ては，米国・カナダと欧州連合（EU）の間の, いわゆる牛肉ホルモン紛争がある. 北米では, 牛 の飼育効率を高めるため, エストロジェンなど数 種類のホルモンが使用されてきたが，これらの使 用が $\mathrm{EU}$ 域内では禁止されていたことから，米 
国・カナダ産の牛肉の大部分は EU 向けに輸出す ることができなかった，ところが，ホルモンは適 正に使用する限り人間に被害がないとの判断を CACが下したところから，EUの禁輸措置は科学 的根拠がないとして，米国とカナダがWTOに提 訴した。紛争調停パネルの報告書は1997年 8 月に 出され，米国とカナダの全面勝訴であった (WTO，1997b).EUはこれを不満として控訴, 1998 年 1 月に公表され翌月採択された控訴体の報 告書は, SPS協定の解釈等についてパネル報告書 を一部変更したものの，原則的にはEUの措置が SPS協定に反しているとして，1999年5月までに 当該の衛生措置を変更するか，あるいは，その措 置を正当化する新たな科学的知見を発表すること を求めた（WTO， 1998).

これはSPS協定に基づいて食品衛生措置の妥 当性を争った初めてのケースであるが，今後も同 種の紛争が提起されることが予想される。一方, WTOを通じた紛争解決の重要性が認識されるに 従い，CACなどを舞台にした国際規格の制定交 渉においては，各国による妥協を許さない利害の 衝突が増えると考えられる。これは，国際的標準 化組織の作業が高度に政治化されるという問題を 含んでいる，CACの場合，その組織運営・意思 決定方式の在り方に関する議論に発展しつつあ り, 国際的意思決定過程への発展途上国の参加が 不十分であるという問題, 単純多数決による規格 採択手続きの是非などが真剣に論じられている (CAC, 1998).

ウルグアイ・ラウンド交渉の終了時までに決着 しなかった事項としては，各国が衛生措置の適用 によって達成しようとする保護水準の整合性に関 する問題と，各国が国際基準を使用している程度 を継続的に調査・把握する方法に関する問題とが ある. SPS協定の実施を円滑に行うために設置さ れたWTOの委員会 (SPS委員会)において，こ れらの問題が議論されているが，1998年末現在, 未だ最終的な解決に至っていない.

\section{2. 食品衛生政策の課題}

世界中の消費者が, その摂取する食品に関して, 科学的な危険評価から導き出された必要かつ十分 な安全基準による統一的な保護を受けるべきであ るという考え方は，「全ての人に健康を」という 理想を追求する上で，正しい方向であると考えら れる（Käferstein and Miyagishima, 1997 ; Miyagishima and Käferstein, 1998 ; Randell et al., 1998)。しかしながら，国や地域ごとに気候条 件や食物摂取習慣が異なるという事情，あるいは 特定の年齢集団など危険許容度の低い消費者をと う保護するかという問題を前に，国際基準の画一 的な運用には限界があることも否定できない。

食糧を輸入に頼る一部の発展途上国にとって は, 高品質・高価格の食糧購入には経済的限界が あり，一歩間違えば，世界中の低品質食品の処分 場になりかねない，一方，食糧の輸出能力がある 途上国においては，自国の農業輸出品が国際規準 を満たしていないとして世界市場から閉め出され れ，経済成長と全般的生活水準が損なわれる危険 を伴う。これらの負の影響を最小限に留めるため には，農漁業技術，衛生分析検査，衛生的食品製 造法等の分野で多国間あるいは二国間の技術援助 が発展途上国に対して与えられる必要がある.

先進工業国においても，事情は単純でない，食 品を介する危険に対する一般市民の感覚は必ずし も，専門家の科学的知見に基づく認識に一致する とは限らない。なぜならば，消費者は在来の危険 には疎く新奇な危険に敏感に反応する心理特性を 持って抢り,さらに一部の消費者には全ての食品 は完全に安全でなければならないという「ゼロリ スク」への信仰も根強い。そこで，一般市民に対 する適切な情報開示と健康教育を通じ，消費者の 要求と科学性とを如何に折り合わせるかが, 各国 政府の食品衛生危険管理の重要なテーマである。

この点で，食品衛生対策に関する政府の意思決 定過程の透明性を高めると同時に，個別の衛生措 置の科学的合理性を要求するSPS協定は，大き な意味を持つ．政府が科学的かつ系統的な危険管 理（risk management）を通じた整合性のある食 品衛生管理を行うためには，定量的な食品安全目 
標を設定する必要があり，その前提として，どこ までの危険ならば甘受するかという閥值（acceptable level of risk）について国民的合意を形 成し，これを食品衛生の分野の中で横断的かつ普 遍的に適用していくことが望まれるが，これは純 粋な科学だけでは割り切れない要素を含むのみな らず技術的にも困難な作業である.

体系的な危険分析（risk analysis）を導入する ための方法論課題も残されている. 食品衛生のな かでも食品添加物, 残留農薬, 残留動物用医薬品 などの化学的危険因子の毒性評価手法は比較的古 くから確立され，国際的にもある程度の合意が形 成されているが，病原微生物に関する危険評価の 手法は発展の途についたばかりである（WHO， 1999).WTOのSPS協定によってもたらされた 新しいルールが今後どのように受け入れられるか は，危険分析を支える科学・技術の進歩に依存す る部分が少なくない.

\section{IV 医薬品・医療機器分野}

\section{1. 品質・技術規格の国際調和}

TBT 協定は，SPS協定が優先的に適用される 農産品に対する衛生・検疫措置に関する部分を除 き，すべての貿易対象品に適用される（GATT, 1994).つまり, 生物製剤を含む医薬品, 診断薬, 医療・福祉機器等は基本的に TBT 協定の対象で ある。

TBT 協定は，SPS協定と同様，国際基準への 調和を通じて各国間の技術的規格を共通化し，差 別的な貿易障壁を聥減しようという考え方に立脚 している.SPS協定との違いの一つは，特定の国 際規格を指定せず，WTOの加盟国のすべてに門 戸が開かれているような任意の国際的標準化組 織, すなわち，国際標準化機構（ISO），国連欧 州経済委員会 (UNECE) などの諸機関が策定す る国際基準に、広く国際調和の目安としての地位 を与えていることである. SPS協定とのもう一つ の違いは, 各国が技術規格を策定するにあたって, ヒト・動植物の生命・健康の保護以外にも，国防 上の要請, 欺瞞的商行為の防止, 環境保護などを
考慮してよいとしていることである（TBT 協定 第 2 条)。これは科学的危険評価を絶対的な判断 基準としているSPS協定と異なる.

医薬品・医薬機器分野においては，それぞれの 国または地域が規定している薬局方等の医薬品の 品質規格・技術規格が TBT協定の対象とされ, これらが不当な国内規格となって非関税障壁とし て用いられることがないように, WTO加盟国間 で配慮がなされるべきこととされている．規制制 度に関する各国の立場と考え方は様々であるが, 医薬品については，一般に，許可された製品以外 の取引を一律に禁止する原則を採用している．規 制の実効性に議論の余地がある場合もあるもの の，医薬の販売や授受を完全に自由としている国 はほとんどない。

各国衛生当局による登録や許可は，各国の保健 医療制度の枠内で行われる保健衛生上の必要措置 であると考えられ，個別の医薬品や医療機器に対 して製品の性質に基づき行われる個別的な措置と いえるが，先進国から途上国に至るまで許可の要 件は様々である．各国の主権として認められる保 健衛生上の必要措置としての医薬品の登録や許可 は，各国政府が負う自国民の健康を守る義務と表 裏一体を成している。

医薬品と農産物の製品としての売買形態を比較 すると, 医薬品の取り引きは許可されたもの以外 は原則禁止であり，農産物は原則自由である。な ぜならば，副作用がない医薬品は存在しない，つ まり医薬品とは元来危険なものであるという前提 があり，製品が使用される対象が疾病に罹患して いる患者等の集団に限られるという事情があるた めである，従って，医薬品あるいはその成分の品 質, 有効性, 安全性が多様であることを踏まえ, 個別的・科学的評価が必要とされてきたのであ る. 最近では, TSE (transmissible spongiform encephalitis，伝達性海綿状脳症）に代表される ように, 農・畜産物由来の原料を用いる医薬品と 農産物そのものに共通する保健上の問題が，国際 的な公采衛生上の課題として注目を集めている例 もある。 
医薬品や医療機器の規制を担当する輸出国や輸 入国の政府機関が科学的基準に基づいて正常に機 能している限り, 個別の医薬品の輸出入をめぐる 問題がWTOの場で貿易紛争の形で取り上げられ る可能性は現在のところ少ないと考えられる。従 って, 医薬品の規格の国際調和が WTOの TBT 協定を軸に進むとは当面考えにくい。むしろ，医 薬品規格の国際調和については, 日本, 米国およ び欧州は, International Conference on Harmonization of Technical Requirements for Registration of Pharmaceuticals for Human Use (ICH) という場を中心に活動を進めてきている，その主 目的は，治療に有用な新しい医薬品をいち早く医 療現場に提供すること，また，そのために人的 . 物的な資源を有効活用することであり，日米欧三 極間での医薬品の許可に係る科学的デー夕の調 和・共通化を図っている.

$\mathrm{ICH}$ は，1991年のブリュッセルの第 1 回会合か ら今日に至る間, 医薬品の開発に関する外国臨床 データの受け入れ等に関して多くの成果を上げて いる. 日米欧三極に属する国々が医薬品市場とし て世界の売り上げの $90 \%$ 占めているだけに， ICH は国際調和促進の上で大きな効果を持ってい る. ICHのガイドライン自体の性格は钊告である が, 新しい医薬品を開発する能力のある三極の 国々における影響力は極めて大きい. 当然, 他の 国々も ICH の成果に大きな関心を寄せており， WHOによって，それらの国々に対して ICHガイ ドラインの橋渡しをする努力が行われている，し かしながら，新薬の開発を目標にICH ガイドラ インを運用できるだけの技術水準を持つ国は限ら れているのが現状である。

一方, WHO 自体も, 医薬品の基準の世界的調 和のために独自の活動を行っている. 食品規格と 同様に, WHO 憲章の第 2 条に基づき, WHOは, 生物製剤を含む医薬品の品質, 安全性に関する規 格またはガイドラインの策定に取り組んできてお り，それらはWHO 総会の議を経て採択されてき た。これらの性格も勧告ではあるが, 生物製剤に 関する品質基準やこれを裏付けるWHO 標準品は
世界中に浸透しており，特に途上国においては， これがワクチン等の接種やその他の保健衛生上の 施策に大きな意味を持つと言われている。しかし ながら，実際に，WTOを軸とする動きが今後ど のようにWHOの医薬品分野の規格を取り込んで いくのかという問題については，その展望があま り開けていない面がある，今後，WTOの動きが 医薬品等の貿易に与える影響, 特に途上国に対す る影響を慎重に評価していく必要がある.

WTO, ICH，そしてWHOをめぐる動きに見 るように，医薬品分野において真にグローバルな 規格を設定することは，困難で時間を要する作業 である。

\section{2. 知的所有権の保護}

医薬品等に関して注目すべきもう一つのWTO 協定は，貿易関連知的所有権協定 (Agreement on Trade-related Aspects of Intellectual Property Rights, TRIPS協定) である (GATT, 1994). 知的所有権については世界的所有権機関 (World Intellectual Property Organization, WIPO) が あり，従前から，知的所有権に関する国内制度の 整備, 国際的な知的所有権の保護等に関する活動 を担ってきたが，国ごとに異なる法制度を強力に 調和させることは困難で, また，これによって生 ずる国と国の間の紛争を解決する機構も存在しな かった。そこで，国によって知的所有権の保護が 著しく異なる実態が貿易に与えるいる障害と歪み を是正すべく，WIPOによって運営されている既 存の知的所有権に関する諸条約と GATT の基本 原則を組み合わせる形でTRIPS協定が締結され た。

これによって, WTO加盟国には，著作権に関 するベルヌ条約と工業所有権（特許）に関するパ リ条約を批准したことと同様に効果が生じること になり，各国は，著作権，商標，意匠，特許など の知的所有榷を保護するのに最小限必要な国内制 度を整備することとされた．知的所有権分野に関 してWIPO とWTOの協働体制が整ったともいえ る. 
但し, TRIPS協定は保健衛生に関し，いくつ かの重要な例外規定を定めている.

第一に，TRIPS協定に違反しない範囲で，各 国が公衛衛生と公衛栄養を保護するための措置を とってよいとされている（TRIPS第 3 条）。この 定めは医薬品等の特許保護を行わないことを積極 的に容認する規定であるというよりも，一般的な 考え方を詔ったものと解釈すべきであるが，一方 で発展途上国に大きく配慮した規定であると考え られている。

第二に, 医薬品・医療機器あるいは微生物とい う「モノ」はTRIPS協定の適用を受けるが，診 断・治療方法や外科手術の術式などの「技術」は, 各国政府の判断で特許保護の対象から外すことが 認められている（TRIPS第27条）.

第三には，第三者利益の保護の観点から，特許 保持者の権利を著しく損なわない限り，医師の処 方箋により調剤された医薬品は特許権の例外とす ることが認められている（TRIPS第 30 条).

そして第四には，各国の法令により，国家緊急 事態や公的かつ非商業的使用の場合には特許権者 の承諾を受けていない使用が認められる場合があ るとされている（TRIPS第31条）.

このように，知的所有権の保護の問題が重要視 されるのは, 医薬品等には，「モノ」としての側 面と, それに付加されている様々な情報や, 開発 過程での投資に裏付けられた製品価值といった次 元とがあり, その意味で, 音楽媒体の著作権など と類似したところがあるからである。そのため， 医薬品等をめぐる貿易上の問題は，TRIPS協定 に絡む医薬品・医療機器の知的財産権に関わる問 題や品質, 安全性や有効性に関するデー夕（臨床 試験以外の部分を含む）の利用に関する問題とし て，あるいは，その公正な販売をめぐる問題とし てクローズアップされている (Correa, 1995).

\section{3. 医薬品・医療機器の供給}

医薬品等の分野は，その製品の付加価值や各国 での販売規制のあり方を見ると, 食品分野に比べ て製品に付随する自由度は少なく, WTO協定の
下では少々特異な存在といえる．医薬品について は個別の製品毎に先進工業国に知識と技術が集積 しており，また，世界各国がそれぞれ保健衛生上 の観点から評価を行う体制になっていることか ら，グローバルな国際規格が発達しにくい．従っ て，WTO協定との関係においては，TRIPS協定 に関する事項が重要な問題であろう.

TRIPS協定が，新しい医薬品を人類に提供し 続ける前提となる開発者の知的財産権の保護手段 として重要であることは言うまでもない，今日， 新規の医療品および高度の医療機器の開発には莫 大な資金が必要である．発売後一定期間，当該製 品に関する特許権が保護されなければ，製薬企業 は自らの投資に見合う額を市場から回収すること ができない. 実際, 新規に開発された医薬品は概 して価格が高く，それを購入できるのは先進工業 国の消費者に限られる場合が少なくない.

公衆衛生に絶大な寄与をする可能性のある医薬 品であっても, 先進工業国での開発企業の特許保 護期間または排他的独占権を行使できる期間が終 了し，他の製薬企業が同製品（後発品）を生産し 始め，その価格競争を通じて価格が下落するまで は，発展途上国は容易に新薬の恩恵にあずかるこ とができない. その医薬品を特定のブランド名や 商標の下に販売するような場合に支払うべき相応 のロイヤリティーの問題もあるが, 公衆衛生の向 上を目指す発展途上国が直面している諸問題の中 で, 医薬品の価格が特に重大となっている.

先端的製薬企業の新医薬品開発意欲を確保しつ つ，一方では発展途上国の医療需要に応えるのは 難問であるＷHOの選定する必須医薬品は 300 品目程度あり,これらの多くは特許で保護されて いる医薬品ではないため，これらを安定供給する ことができれば，発展途上国の最低限の医療需要 を満たすことは一応可能である，ところが，エイ ズのような疾病の大規模な感染流行が発展途上国 で起こり, 最新の治療薬が広く求められるという ような場合に, 途上国の治療薬へのアクセスをど のように解決していくべきであろうか.このジレ ンマと, 発展途上国におけるいわゆる偽医薬品お 
よび偽ブランド医薬品（counterfeit drug）の問 題は決して無関係ではなく, 恵まれない経済条件 に共に根ざしている。

医薬品等に関する広告および外国での医薬品使 用に関する情報は，インターネットなどを通じて 瞬時に世界を駆けめぐる時代となった。これによ って, 欧米先進国と同等の医療を受けたいという 願いが世界中の消費者に共通の心情となりつつあ るが, 付加価值の高い医薬品等の開発・製造・供 給に関する限り, 先進工業国側の発展途上国に対 する圧倒的優位は当分変わりそうもない.こうい った医薬品供給に関する途上国の不安感を背景と し，1996年の世界保健総会において, WTO協定 が世界の医薬品供給に与えるインパクトを調查す ることが決議された（WHO， 1996）。これに応 える形でWHO 事務局は途上国向けにTRIPS 協 定について解説した文書を作成したが（WHO， 1997)，1998年の WHO 総会においてもこの問題 をめぐる議論は継続され, 国際的な保健推進の観 点から TRIPS協定をどう評価すべきかの最終的 な結論は得られていない。

途上国側は, TRIPS協定が医薬品へのアクセ スや価格に対しての負の影響を与えると懸念し, TRIPS第 8 条を根拠として, 経済的な利害よりむ しろ公衆衛生上の利益が優先すべきであると主張 している．世界の保健衛生を議論すべきWHOの 場で間接的に経済問題の議論をしている観がある が, 現時点でTRIPS協定の保健衛生上の意義は 未だ明らかにされていない. 先進国における医薬 品開発に伴う知的財産権を保護するという観点の みならず, 途上国における適正な医薬品産業の発 展を促すという観点からも, TRIPS 協定の果た す役割を注意深く分析することが必要不可欠であ る. それと同時に，途上国側への技術支援等の問 題も国際社会の課題である.

\section{V 保健医療サービス分野}

\section{1. 保健医療サービス貿易}

保健医療サービスの貿易は, 国内外のサービス 提供者間の競争による質の向上と価格の低下, 国
内市場では得られない特殊なサービスへの消費者 のアクセスの確保, 各国の特色を生かしたサービ ス領域への重点化を通じた国際分業, 国内の余剩 サービス供給設備を用いたサービス輸出による外 貨獲得などの利点をもたらすことが知られてい る. 一方, 短所としては, サービス貿易が行われ るためには国内の保健医療サービス市場の一定程 度の自由化が前提となることから, 競争力のない 国内業者の経営が圧迫されること，あるいは，国 民の保健医療資源への平等なアクセスが阻害され る可能性を生む危険性などが指摘されている (Adams and Kinnon, 1997).

保健医療サービスを提供する専門職に特徵的な 条件を, 仮に法律・会計サービスの専門職と比較 すると, 後者は事業を行う国・地域の法律制度の 知識が不可欠であるのに対して, 前者は普遍的な 医学知識がベースになっており，これはサービス 貿易を容易にする点である。これに対し, 医療サ ービス貿易に特有の制約としては, 国ごとの言語 や医療文化の違い, 医療保険の外国受給制限, 市 場独占的な国営医療制度の存在などがある.

WTOのサービス貿易に関する一般協定 (General Agreement on Trade in Services, GATS) は，それまで「モノ」の貿易に限られていた GATTの守備範囲を「モノ以外」に拡大した点 でウルグアイ・ウンンド交涉の画期的な成果のひ とつに数えられている．この協定は,「政府の権 限の行使として提供されるサービス以外のすべて の分野におけるすべてのサービス」を対象とし, これを 4 つの型に分類している（GATT， 1994 ; 表2).サービスと名のつくものはほとん どがGATSの対象となるが, 保健医療に関連す るサービスとしては, 医師・歯科医師・看護婦・ 助産婦・理学療法士などの専門職が提供するサー ビス, 医業コンサルタントサービス, 医学・保健 医療教育, 環境保全サービス, 保健医療・社会事 業（病院, 福祉施設等の設置・運営）がある.

GATSには一般的な例外条件が定められてお り, 公序良俗の維持, 人命と健康の保護などの正 当な理由があるならば, 当該国の文化あるいは宗 
表 2 サービス貿易のモード分類

\begin{tabular}{|c|c|c|}
\hline & GATS 第 1 条 2 項によるモード分類 & 医療分野での例 \\
\hline 1 & $\begin{array}{l}\text { ある加盟国の領域から別の加盟国の領域へのサービス } \\
\text { の提供(越境サービス) }\end{array}$ & $\begin{array}{l}\text { 遠隔診断, 䀢薬の通信販売・ } \\
\text { 購入 }\end{array}$ \\
\hline 2 & $\begin{array}{l}\text { ある加盟国の領域内にお目けるサービスの提供であって } \\
\text { 別の加盟国のザ費者に対して行われるもの } \\
\text { (外国でのサービス購入) }\end{array}$ & $\begin{array}{l}\text { 外国での診療(臓器移植手術 } \\
\text { など), 外国での薬郕売買 }\end{array}$ \\
\hline 3 & $\begin{array}{l}\text { ある加盟国のサービス提供者によるサービスの提供で } \\
\text { あって別の加盟国の領域内の業務上の拠点を通じて行 } \\
\text { われるもの(コマーシャル・プレゼンス) }\end{array}$ & $\begin{array}{l}\text { 外国系医療機関の支店開設, } \\
\text { 外国系医療保険の売買 }\end{array}$ \\
\hline 4 & $\begin{array}{l}\text { ある加盟国のサービス提供者によるサービスの提供で } \\
\text { あって別の加盟国の領域内の加盟国の自然人の存を在を } \\
\text { 通じて行われるもの }\end{array}$ & $\begin{array}{l}\text { 外国医師による診断治療(出 } \\
\text { 張手術など), 傷病人の国際 } \\
\text { 搬送 }\end{array}$ \\
\hline
\end{tabular}

教に照らして受け入れられないある種の医療行為 （例えば人口妊娠中絶や去勢）の提供を目的とす るサービスは当該国政府が禁止する対象になりう る(GATS20条).

交涉の過程で明らかになった加盟国の考え方の 違いを反映し，GATSは加盟国に対して後述する ような義務免除を認める一方, 今後の更なる自由 化を二国間・多国間交渉を積み上げながら漸進的 に進める立場が取られている，GATSのもとで加 盟国が負う義務は 2 種類に分けられる。

第一に，最恵国待遇（外国のサービス提供者間 での差別の禁止）と透明性（サービスに関する新 たな法制に関する他の加盟国への情報提供）は， すべてのサービスに及ぶ義務である，ただし，各 国は，自国内に扔いて最恵国待遇を当面適用した くない分野を第 2 条例外表に書き込んでおくこと ができる.

第二に，加盟国が予め約束した分野に限って適 用される義務として，市場アクセス（GATS16条） と内国民待遇（GATS17条）がある，これらの自 由化を約束するサービス分野は，やはり国別の約 束表に書き込まれている，自由化約束は後から追 加することができるが，原則として撤回すること はできない，また，いったん開放した分野につい ては最恵国待遇を保障しなければならない。ただ し，GATSの規定とは別に，各国は主権国家に通 常許される出入国管理措置をとることができるた め, GATSにおいて自由化約束がされている分野
の労働市場が無条件で外国人に開放されるわけで はない.

ウルグアイ・ラウンド協定が調印された 1994 年 4 月の時点で特定の自由化約束を提出していた 95 力国のうち, 半数近い 59 力国が保健医療サ一 ビス分野で一つ以上の約束をしており，それは先 進国・条展途上国を問わず，世界の全地域に分布 している（Butkeviciene and Diaz，1998）.

\section{2. サービス輸出の諸類型}

保健医療サービスの輸出に積極的な国は，次の ような類型に分かれる。

第一は，保健医療サービスが相対的に低いコス トで提供できる利点を生かす場合である。メキシ コはその好例で，米国人・カナダ人あるいはメキ シコ系北米移民の顧客（患者）を対象にした医療 施設を米国国境沿いの都市に整備している．北米 居住者にとっては，同程度の医療が自国よりも安 価に受けられるメリットがある、メキシコの特定 の医療機関での受診受療を給付対象に含めている 米国の健康保険も存在する (Arrendono-Vega, 1998). 同様に，キューバは海外患者の積極的な 誘致を進めた結果，1995／1996年の期間にキュ 一バで治療を受けた外国患者は 25,000 人に及び， これにより 2,500 万米ドル相当の外貨収入を上げ ているという報告がある（UNCTAD，1998）。

第二は，自国の歴史的文化的特徵を生かした他 国では得られにくい保健医療サービスを提供する 
場合である．例えば，中国の北京及び沿海部諸都 市に立地する医療機関では, 中国の伝統医学に基 づく保健医療サービスを短期滞在外国人あるいは 在外華僑に対して提供している（Xing， 1998）.

第三は，高水準の保健医療技術の輸出を行う場 合である，顕著な例は米国であり，疾病診断に関 する優秀な技術を先進的な画像通信技術と組み合 わせることにより，湾岸諸国をはじめとする外国 の契約医療機関に遠隔診断サービスを提供してい る。英国においても，医療システム海外事業団 (National Health System Overseas Enterprise) が海外への保健医療サービス輸出促進の仲介を行 うと同時に，国内の保健医療従事者の在外研修に も貢献している（UNCTAD， 1998）.

\section{3. 保健医療の市場開放}

保健医療サービス分野は, 現行のWTO協定の 下では市場開放が当事国の主体性に任されている こともあり，その貿易は未だ発展途上にあると考 えられる。保健医療サービスの市場が国家の強い 統制下に扔かれている国は, 先進工業国, 発展途 上国を問わず少なくない。そこで，保健医療サー ビス貿易のもたらす可能性を探るためには，サー ビス市場の開放によって保健医療サービスの利用 者がどのような利益を得られるかを検証する作業 を各国それぞれが行う必要がある。この検証作業 の結果次第で，国内市場を開放すべきか閉鎖を維 持すべきかの政策判断を下すことが可能になる.

サービス輸入の長所を取り込む方法として，例 えば，専門職種の相互資格認定条約等を通じた参 入条件の緩和を行ったり（宮城島，1994）, 在留 外国人に対する医療サービス提供等に目的を限定 して外国医療機関の参入を認めたりすることが行 われている.

これらはどの国においても選択可能な政策オプ ションであるが，発展途上国に対しては，医療サ ービス貿易の自由化は特に大きなインパクトを与 えうる. 途上国にとって自国の市場を開放するこ とは，既存の医療資源（病床等）が一部外国人に 振り向けられてしまい，自国民のためのサービス
供給力が実質的に減少してしまうという負の影響 が予想される一方, 富裕層が別立ての医療制度に 移行することによって, 大衆向けの医療機関の混 雑が改善される可能性もあるからである (Adams and Kinnon, 1997).

\section{VI その他の貿易交渉および国際投資}

WTOを舞台に進行中の貿易自由化と保健医療 の関連の密接化は, SPS協定, TBT協定, TRIPS協定, GATSという四つのWTO協定の範 囲に限定されない. 例えば, ウルグアイ・ラウン ド交渉では日米欧が医療・診断機器等について関 税の撤廃あるいは莪減の合意をしたことにみるよ うに，関税障壁の撤去を通じて保健医療分野の 「モノ」の貿易を促進する動きが見られる。これ は今後，ハイテク医療機器が自由に貿易されるよ うになる方向を示唆している.

医療関連機器の関税引き下げに加え，1996年 のシンガポールのWTO閣僚会議において合意さ れた情報機器の貿易に関する宣言（WTO Ministerial Declaration on Trade in Information Technology Products, ITA）を皮切りに, 情報関連 機器の段階的非関税化の動きは, 現在も ITA-II として継続中である.このITAの成果も先進的 な医療機器の普及をさらに加速すると予想され る.

さらに, 2000 年から始まる次期ラウンド交渉 の焦点のひとつと言われている国際投資の自由化 が保健衛生に与える影響も過小評価できない (Anonymous, 1998). その直接影響は，保健医 療サービスが公的に担われている国においてより も，私的企業活動によって担われている国におい てより大きいと考えられ, 従って, 投資自由化の 保健医療への影響の大きさは，既存のWTO協定 と同じく，国ごとに異なると予想される．それは 雇用や労衝衛生に対する国際的投資協定の間接的 影響についても同様である.いずれにしても，保 健医療あるいは社会福祉の領域での投資の自由化 は, 国内市場に揖ける競争を促進する効果があり， その動向は保健医療市場の開放を当面行わないと 
している国にとっても目が離せない.

\section{VII 発展途上国の問題}

発展途上国に対するWTO協定の負の影響を最 小限に抑え，貿易を通じた経済発展を促進するた めに，多くのWTO協定には，（1）一部の協定義 務の期限付き又は期限を特定しない唒予，および （2）技術協力に関する条項が盛り込まれている (WTO, 1997a).

TRIPS協定は，発展途上国に対して，協定発 効後 5 年から 10 年の猶予（西暦 2000 年もしくは 2005 年まで）を与え, 後発発展途上国（LDC） に対しては更に延長を認める余地を残している (TRIPS協定第65-66条)。一方，SPS協定は，発 展途上国に対して，協定発効後 2 年の猶予（西暦 1997 年まで）を与え，後発発展途上国（LDC） に対しては 5 年の猶予（西暦 2000 年まで）を認め た上で (SPS協定第 14 条)，さらに個別の例にお いて途上国の情状を酷量するとしている（SPS協 定第 10 条).

義務履行の猶予については, 協定の内容によっ ては，猶予期間が既に終了したものもあり，遅か れ早かれ全てのWTO加盟国が同じ条件で協定に 参加することになる。一部の発展途上国には， WTOの協定全体が先進国に有利にできていると して，途上国に対する特別措置の継続ないし強化 を求める声があり，これは 2000 年から始まると されている新たなラウンド交渉の議論に少なから ず影響を与えると思われる。

技術協力については, 多くの発展途上国が先進 国あるいは国際的な専門機関に対して，技術援助 の要請を行っている。そののちの一部は実行され ているが，各国の援助財政資金不足のため，十分 な援助が供与されているとは言い難い.

\section{VIII 結 語}

WTOの体制の下での貿易自由化は，まさにグ ローバルな流れに沿ったものである．先進工業国 であるが発展途上国であるかを問わず，一つ一つ のWTO協定について個別に当該国にとっての経
済的・社会的損得を論ずることは余り意味がな く，WTO体制全体がもたらす自由貿易促進の効 果という観点から判断がなされなければならな い．例えば，TRIPS協定は多くの途上国にとっ てメリットが少ないかもしれないが，農薬製品や 繊維製品について先進国の市場が開放されて途上 国からの輸出による外貨収入が増えれば，途上国 の国民生活の向上につながり，結果としては総合 的に得策であるという場合も考えられる．分野別 の得失が両極端に分かれるような場合には，輸出 振興を主張する勢力（市場開放派）と保健福祉の 現状水準を確保しょうとする勢力（市場閉鎖派） の間で政治的に微妙な舵取りが迫られることもあ りえるであろう。各国政府においては, WTO戦 略の策定に関し，従来のように外交・通商・産業 担当部局だけの意見を集約するのではなく, 保健 衛生・社会保障担当部局との調整を十分に行って いく必要がある。

貿易に関する各国の世界戦略を見ていく際，国 際機関の場を通じて貿易ルールの共通化を図って いこうとする立場（多角的スキーム）と，地理的 な地域ブロックの内部でのルール共通化を優先し ていこうとする立場（地域的スキーム）の対立を 見落とすことはできない．前者の代表的活動が WTOであるとすれば，後者には北米自由貿易圈 (NAFTA), 南米共同市場（MERCOSUR），欧 州共同体（EC），東南アジア諸国連合（ASEAN） などがある。アジア太平洋経済圈 (APEC) が貿 易交渉の場となることも増えたが，共通市場の創 設を目的に揭げた先発の諸組織に比べると，地域 経済組織と呼ぶには現状では語弊がある。多角的 スキームと地域的スキームの両方に所属する国 は, ケースバイケースで国益に最も叶う方法で外 交戦術を決めていけばよいが，例えば日本のよう に，いかなる地域経済機構にも属していない国に あっては, 専ら多角的スキームを活用して国際社 会における発言権を確保していくほかに選択肢は ない.

別の角度から見るなら, ウルグアイ・ラウンド において大きな発言力を維持したのが自由貿易指 
向の農産品輸出国群，いわゆるケアンズグループ であったとすれば，2000年に始まる見込みの次 期貿易交涉においては，日本，欧州連合（EU） などの消費者の健康保護に大きな関心を寄せる諸 国が，一体としてイニシアチヴをとることも考え られる. 次のラウンド交涉では, 従前からのテー マであるモノの関税聥減, サービス貿易の一層の 自由化などに加えて，投資，公正競争，労働基 準・労働条件, 貿易と環境などに関する新たなル ール作りが期待されている．特に後二者は，保健 福祉と密接な関連があり，各国の社会政策との干 渉が予想されることから論議の的になるものと思 われる（渡辺，1997）。

WTOに象徵される新国際貿易秩序を通じた経 済のグローバル化は，21世紀の前半までに，世 界の市場の統合をかなりの速さで進めていくであ ろう。そこに立ち現れる世界は, 経済活動に関す る国境が存在しない世界，言い換えれば，商品と サービスの生産主体と消費主体が同じく国に立場 する必然性がない世界である。そこにおいては, ある国の社会保障制度が企業にとって経済負担が 大きい割に被雇用者に対して魅力ある給付を行え ないものであるとき，商品やサービスを生産する 企業は，より効率的で低コストの社会保障制度を 実現している国に移転することを躊躇しないであ ろう。一方, 優秀な頭脳労働者は, より生産性の 高い企業が立地する国に向けて移動していくと予 想される。

21 世紀においては，産業の国際競争力を高め るだけでなく，その国の社会保障制度の効率性を 相対的に高めることが国家の経済政策として要求 される．保健医療分野および社会福祉分野の市場 開放ないし市場共通化をその手段として用いるこ とを検討する必要も生じょう。

\section{文献}

Adams O, Kinnon C (1997): Measuring trade liberalization against public health objectives: the case of health services, WHO Task Force on Health Economics (unpublished document, WHO/TFHE/ TBN/97.2)
Anonymous (1998) : Fifty years at GATT, The Economist, May 16, 19-23

Arredondo-Vega JA (1998) : The case of the United States-Mexico border area, Zarrilli and Kinnon eds., International Trade in Health Services: A Development Perspective, 161-174, UNCTAD (Geneva) and WHO (Geneva)

Butkeviciene J, Diaz D (1998) : GATS commitments in the health services sector and the scope for future negotiations, Zarrilli and Kinnon eds., International Trade in Health Services: A Development Perspective, 135-158, UNCTAD (Geneva) and WHO (Geneva)

CAC (1998) : Report of the Thirteenth Session of the Codex Committee on General Principles, Codex Alimentarius Commission, ALINORM 99/33, Joint FAO/WHO Food Standards Programme (Rome)

Correa MC (1995) : Impact of WTO globalization of trade on pharmaceutical sector, WHO (Geneva)

Croome J (1995) : Reshaping the World Trading System, WTO (Geneva)

Davey WJ（1997）：WTO システムに扩ける紛争解 決に関する諸問題，貿易と関税，78-93

GATT (1994) : The Results of the Uruguay Round of Multilateral Trade Negotiations: The Legal Texts, GATT Secretariat (Geneva)

Käferstein FK, Miyagishima K (1997) : Codex Alimentarius and its importance for public health, World Food Regulation Review, 7 (2) , 21-23 宮城島一明（1994）: 医師資格の国際認知, 医学教育, 25 (3) , 177-182

Miyagishima K, Käferstein FK (1998) : Food safety and international trade, World Health Forum, 19, 407-411

Randell AW, Miyagishima K, Maskeliunas J (1998) : Codex Alimentarius Commission: protecting food today and in the future, Food, Nutrition and Agriculture, 21, 18-22, FAO (Rome)

UNCTAD Secretariat (1998) : International trade in health services: difficulties and opportunities for developing countries, Zarrilli and Kinnon eds., International Trade in Health Services: A Development Perspective, 3-34, UNCTAD (Geneva) and WHO (Geneva)

Wallach LM (1998) : Le nouveau manifeste du capitalisme mondial, Le Monde diplomatique, février 1998

渡辺幹彦（1997）：WTO 制度下の貿易自由化と環境 問題，環太平洋ビジネス情報 RIM，35号，さくら 総合研究所（東京） 
WHO (1996) : Revised drug strategy, WHA49.14, May 1996, WHO (Geneva)

WHO (1997) : Globalization and access to drugs, implications of the WTO/TRIPS Agreement, Action Programme on Essential Drugs, WHO (Geneva)

WHO (1998) : Food Safety and Globalization of Trade in Food: A Challenge to the Public Health Sector, WHO/FSF/FOS/97.8 Rev. 1, WHO (Geneva)

WHO (1999) : Report of the Joint FAO/WHO Expert Consultation on Risk Assessment of Microbiological Hazards in Foods, WHO (Geneva)

WTO (1995) : The WTO Dispute Settlement Procedures: A Collection of the Legal Texts, WTO (Geneva)
WTO (1997a): The WTO and Developing Countries, WTO (Geneva)

WTO (1997b) : EC measures concerning meat and meat products (hormones), Complaint by the United States, Report of the Panel ( WT/DS26 /R/USA), 18 August 1997, WTO (Geneva)

WTO (1998) : EC measures concerning meat and meat products (hormones) : Report of the Appellate Body (WT/DS26/AB/R), 16 January 1998, WTO (Geneva)

Xing H (1998) : The case of China, Zarrilli and Kinnon eds., International Trade in Health Services: A Development Perspective, 189-211, UNCTAD (Geneva) and WHO (Geneva)

（受稿 1999.1.4；受理 1999.7.16） 